\title{
Response to commentaries on 'Caster Semenya, athlete classification, and fair equality of opportunity in sport'
}

\author{
Sigmund Loland
}

I appreciate all of the commentaries as they raise a series of critical and constructive points. Due to limited space, I can only address some of the issues in brief ways.

Knox and Anderson indicate that classification according to testosterone levels should be applied only at the elite level and with a more inclusive approach in amateur and recreational sport. Indeed, I agree, and this is also the case in the International Association of Athletics Federation's (IAAF) Differences of Sexual Development (DSD) regulations that hold only for international events.

A second comment questions whether my use of the adjective 'systemic' adds meaning beyond what is already included in 'stable inequality'. I find 'systemic' useful as it emphasises inequalities with effects more or less on the whole organism, but I am definitely open for improving the terminology.

A third comment relates to whether inequalities must be inborn to justify classification. This is a valid point, and I need to be more precise. Inequalities need not be inborn. For instance, as Knox and Anderson note, stable testosterone levels can be outcomes of hormone therapy as in the case of elite transwomen athletes.

Chambers challenges my view that sport is structured on a luck egalitarian principle. She points to significant impact of inequalities in socioeconomic strength, and of uncontrollable factors in competition: an unlucky draw in a tournament, a sudden gust of wind affecting an archer's shot or an acute injury. In spite of imperfect procedures, I still think luck egalitarianism is a regulative and structuring idea. There is a general sense in sporting communities that socioeconomic inequalities are unfair as exemplified by attempts on regulation: caps on salaries in American sport, 'financial fair play rules' in European soccer, Olympic solidarity funds to expand sport in underdeveloped areas. Other kinds of luck are incorporated as part of the skill

Correspondence to Sigmund Loland, Institute of Sport and Social Sciences, Norwegian School of Sports Sciences, Oslo, Norway; sigmund.loland@nih.no challenge. A good soccer team copes with lucky/unlucky tournament draws, good archers adjust to variable wind conditions. 'The more I practice, the luckier I get', as the saying goes. Luck egalitarianism will take various forms depending on the nature of the practice under examination. Compensating for inequalities in testosterone levels may make sense in sport but has no rationale in research, or in politics or in business.

Carpenter elaborates on the broader context and impact of IAAF's DSD regulations. I acknowledge many of his points, I realise that athletes affected pay a significant cost, and I acknowledge the risk of stigmatising and violation of rights. Moreover, I share Carpenter's view of the unacceptability of surgical and pharmacological intervention to conform to sport classification and agree on the premise that sex assigned by birth should always be respected. At the same time, in middle distance running, there is also a cost on women within the statistically normal range as DSD athletes have an advantage. This challenges the fair equality of opportunity norm and can be a signal to aspiring athletes that it takes elevated testosterone levels to succeed. I therefore follow CAS view of the Semenya case as a dilemma of rights. Carpenter's commentary however is a strong reminder of the significance of the wider impact of sporting regulations which, unfortunately, is often overlooked in the deliberations of sporting institutions.

All commentaries deal with and problematise to varying degree the distinction between stable and dynamic inequalities. There seems to be agreement that the distinction make some sense in obvious cases such as sex and weight classes in combat sports, and sex classes in track and field. The main criticism relates to whether the distinction can provide rationale for endogenous testosterone levels as criterion for classification.

Chambers and Carpenter reject the possibility and conclude that DSD athletes should be categorised according to 'established physiological definitions' of male and female (Chambers) or 'sex assigned by birth' (Carpenter). Camporesi acknowledges the fairness challenge but is critical to the DSD regulations and classification and suggest other solutions. Knox and Anderson point to the possibility of even more fine-tuned classification schemes.

Camporesi and Chambers see precedence as a problem. First, why do regulations on testosterone levels hold only for women? What about male athletes with levels far beyond what is statistically normal? Second, if we accept testosterone levels as a classification criterion, what other inequalities should be compensated for? Camporesi provides the example of Finnish cross-country skier Mäntyränta who, due to a genetic mutation (EPOR), produced enhanced levels of red blood cells. Should endurance athletes with the EPOR mutation be treated in similar ways as track and field DSD athletes in the women's class?

These are valid questions. My response would be principled in kind. If there are athletes with stable haematocrit or testosterone levels far beyond upper limits of the statistically normal in their competition class (men's and women's class), and if these inequalities exert significant and systematic impact on performance, noneligibility and new classification schemes should be considered.

Knox and Anderson (and Camporesi) point to possibilities of even more fine-grained classification, perhaps also including what I define as dynamic inequalities. There is need for a word of caution, however. Competitive sport is not a scientific experiment striving for complete elimination of non-controllable and 'confounding' variables. ${ }^{1}$ Performances are complex and fascinating expressions of how athletes deal with their potential with own efforts primarily. As detailed above in my response to Chambers, coping with some forms of luck are even included in the skill test. Classification is designed to take out significant and systematic impact of stable inequalities that athletes cannot control or impact in any significant way: in sex, body size, age. Fine-grained classification schemes based on a high number of anthropometric and biological inequalities contradict the nature of sport.

Contributors I am the sole contributor of the manuscript.

Funding The authors have not declared a specific grant for this research from any funding agency in the public, commercial or not-for-profit sectors.

Competing interests None declared. 


\section{Response}

Patient consent for publication Not required.

Provenance and peer review Commissioned; internally peer reviewed.

\section{(2) OPEN ACCESS}

Open access This is an open access article distributed in accordance with the Creative Commons Attribution Non Commercial (CC BY-NC 4.0) license, which permits others to distribute, remix, adapt, build upon this work non-commercially, and license their derivative works on different terms, provided the original work is properly cited, appropriate credit is given, any changes made indicated, and the use is non-commercial. See: http://creativecommons.org/ licenses/by-nc/4.0/.

(C) Author(s) (or their employer(s)) 2020. Re-use permitted under CC BY-NC. No commercial re-use. See rights and permissions. Published by BMJ.

\section{(D) Check for updates}

To cite Loland S. J Med Ethics 2020;46:599-600.

Received 30 July 2020

Accepted 30 July 2020

Published Online First 21 August 2020

\section{S Linked}

- http://dx.doi.org/10.1136/medethics-2019-105937

- http://dx.doi.org/10.1136/medethics-2020-106506

- http://dx.doi.org/10.1136/medethics-2020-106508

- http://dx.doi.org/10.1136/medethics-2020-106509

- http://dx.doi.org/10.1136/medethics-2020-106748

$J$ Med Ethics 2020;46:599-600.

doi:10.1136/medethics-2020-106755

\section{REFERENCE}

1 Loland S. Sport: a scientific experiment? Sport Soc 2019;22(9):1501-11. 